\title{
Medicinal Properties of Chilli Pepper in Human Diet: An Editorial
}

\author{
Subha Ganguly ${ }^{1}$, Praveen Kumar Praveen ${ }^{2}$, Parveez Ahmad Para ${ }^{3}$ and Vijay Sharma ${ }^{2}$ \\ ${ }^{1}$ Associate Professor, Department of Veterinary Microbiology \\ ${ }^{2}$ Assistant Professor, Department of Veterinary Public Health and Epidemiology \\ ${ }^{3}$ Assistant Professor, Department of Livestock Products Technology, Arawali Veterinary College \\ (Affiliated With Rajasthan University of Veterinary and Animal Sciences, Bikaner), Rajasthan, India.
}

\begin{abstract}
The chili pepper also known as chilli grows on plants of the family, Solanaceae, The intensity of the flavor in chilli peppers when ingested is due to the presence of capsaicin (8-methyl-N-vanillyl-6-nonenamide) and several other related group of chemicals called capsaicinoids.
\end{abstract}

Keywords: Chilli pepper, Medicinal value, Nutritional importance

\section{INTRODUCTION}

The origin of chilli peppers is from Mexico. They were transported to the Asian subcontinent by the Portugese navigators during the $16^{\text {th }}$ century.

After ingestion, the capsaicinoids bind with pain receptors in the mouth and throat that are responsible for sensing heat. After activation the receptors the brain responds to the burning sensation by increasing perspiration, raising the heart rate and by releasing the endorphins. Research has proved that capsaicin alters the pattern of utilization of energy by the body cells through ATP hydrolysis.

The "heat" of chili peppers is measured in Scoville heat units (SHU), which is a measure of the extent of chilli extract dilution when added to sugar syrup before its heat becomes undetectable to a panel of tasters; the more it has to be diluted to be undetectable,

\section{Medicinal and Nutritional Properties}

Red chillies are nutritionally enriched with vitamin $\mathrm{C}$ and small amounts of carotene (provitamin A). Yellow and especially green chilies contain a considerably lower amount of both substances. Peppers are also a rich source of Vit. B-complex and especially Vit. $\mathrm{B}_{5}$ particularly. These are rich source of iron, magnesium and potassium. The high content of vitamin $\mathrm{C}$ content substantially increases the utilization of non-heme iron from the beans and grains.

\section{SUMMARY}

British Medical Journal has published a population study where it is indicated that the human who consume spicy foods and more of chilli peppers are less likely to suffer from cardiac ailments, cancer and/or diabetes.

\section{REFERENCES}

[1] Bosland, P.W. (1998). Capsicums: Innovative uses of an ancient crop. In: J. Janick. Progress in new crops. Arlington, VA: ASHS Press, pp. 479-487.

[2] Van Zonneveld, M., Ramirez, M., Williams, D., Petz, M., Meckelmann, S., Avila, T., Bejarano, C., Rios, L., Jäger, M., Libreros D., Amaya, K. and Scheldeman, X. (2015). Screening genetic resources of Capsicum peppers in their primary center of diversity in Bolivia and Peru. PLoS ONE, 10 (9): e0134663. doi:10.1371/journal.pone.0134663 
[3] Kosuge, S., Inagaki, Y. and Okumura, H. (1961). Studies on the pungent principles of red pepper. Part VIII. On the chemical constitutions of the pungent principles. Nippon Nogei Kagaku Kaishi (J. Agric. Chem. Soc.), 35: 923-927; (en) Chem. Abstr., 1964, 60, 9827g.

[4] Yasser A. Mahmmoud (2008). Capsaicin stimulates uncoupled ATP hydrolysis by the sarcoplasmic reticulum calcium pump. Journal of Biological Chemistry, 283(31): 2141821426. doi:10.1074/jbc.M803654200

[5] Paul Rozin and Deborah Schiller (1980). The nature and acquisition of a preference for chili pepper by humans. Motivation and Emotion, 4 (1): 77-101. doi:10.1007/BF00995932 